\title{
Role of trehalose on antioxidant defense system and some osmolytes of quinoa plants under water deficit
}

\author{
Mervat Shamoon Sadak ${ }^{*}$, Hala Mohammed Safwat El-Bassiouny and Mona Gergis Dawood
}

\begin{abstract}
Background: For scavenging reactive oxygen species, plant possess effective system that protect them from destructive oxidative reaction. Parts of this system as osmoprotectants and antioxidative enzymes are key elements in the defense mechanisms. A field experiment was conducted to evaluate the potential of foliar treatment of trehalose (Tre) with different concentrations $(0,0.1 \mathrm{mM}$, or $0.5 \mathrm{mM})$ in improving antioxidant defense system of quinoa plant under normal irrigation and drought stress conditions.
\end{abstract}

Results: Drought stress caused significant increases in some osmoprotectants as glucose, trehalose, TSS, free amino acids, and proline. Meanwhile, trehalose foliar treatment with different concentrations significantly decreases in free amino acids and proline contents. More accumulation of the tested organic solutes of leaves (glucose, sucrose, trehalose, TSS) of the trehalose-treated plant in both normal irrigated and drought-stressed quinoa plants as compared with the corresponding controls. Treating quinoa plants with trehalose resulted in significant decrease in lipid peroxidation, hydrogen peroxide contents, and LOX activity in normal irrigated and drought-stressed plants. These decreases correlated with significant increases in total phenolic contents as compared with untreated control. Different concentrations of trehalose resulted in significant increases in antioxidant enzymes. Maximum increase antioxidant enzymes were observed by treating plants Tre at $0.5 \mathrm{mM}$ either under normal irrigation or drought conditions.

Conclusion: It could be concluded that foliar spray of trehalose was effective in improving quinoa performance by reducing hydrogen peroxide free radical and by enhancing antioxidant compounds (phenolics), compatible osmolytes, membrane stability, and antioxidant enzymes.

Keywords: Antioxidant enzymes, Drought, Phenolics, Proline, Quinoa, Trehalose

\section{Introduction}

Quinoa as a newly introduced food crop can replenish part of food gap. It is considered as a multipurpose crop, and seeds can be utilized for human food, in flour products, and in animal feedstock because of its high nutritive value (Bhargava et al. 2007). Quinoa can grow in sandy soil of arid and semiarid regions in addition to its tolerance to salinity, drought, and other abiotic stresses which reduce crop production (Fuentes et al. 2012). Quinoa seeds was recognized as high-quality protein seeds, especially rich in essential

\footnotetext{
* Correspondence: mervat_sh24@yahoo.co

Botany Department, Agriculture and Biology Division, National Research Centre, 33 El Bohouth st., Dokki, Giza 12622, Egypt
}

amino acids, minerals, carbohydrates, antioxidant compounds as $\alpha$-\& $\gamma$-tocopherol, carotenoids, flavonoids, riboflavin, thiamine, vitamin $\mathrm{C}$, folic acid, and dietary fiber, compared to that of cereals such as corn, oat, rice, and wheat (Repo-Carrasco-Valencia and Serna 2011). Quinoa crop was chosen by FAO as one of the important crops which play major role in food security assuring in the twenty-first century due to its high nutritional value and its good tolerance to adverse climatic conditions. Also, because this crop can grow in sandy soil of arid and semiarid regions, it can be used to replenish part of the food gap.

Water deficiency which is often linked with other major abiotic stress such heat stress, salinity stress, etc. is considered as one of the primary factors responsible 
for crop productivity reduction (Dawood and Sadak 2014). Water shortage caused adverse effect on plants via reduced growth, nutrient acquisition reduction, and modulation, in water status of plants (Sadak 2016b). Protoplasma dehydration increases cellular electrolytes concentrations which cause substantial disturbance in a variety of metabolic reactions in the cell (Mahajan and Tuteja 2005). The reduction of photosynthetic efficiency and stomatal conductance, RuBisCo activity inhibition, and energy balance disruption and distribution during photosynthesis (Demirevska et al. 2010) cause increased accumulation of reactive oxygen species (ROS) under water deficient stress (Hasanuzzaman et al. 2014). Plants have evolved protective mechanisms to perceive and respond rapidly to the adverse environmental cues (Demirevska et al. 2010). These metabolic adaptations that improve plant tolerance to osmotic or water stress involve an increased synthesis of osmoprotectants as free amino acids, proline, and soluble sugars. Compatible osmolytes not only contribute to osmoregulation but they may also protect the structure of different biomolecules and membranes or act as free-radical scavengers that protect DNA from damaging effects of ROS (Ashraf and Foolad 2007). Phenolic compounds accumulation also plays an important role in scavenging free radicals and protects plants against the damaging effects of increased ROS levels due to water stress (Petridis et al. 2012). Moreover, to reduce oxidative damage resulting from water deficiency, plants have developed different adaptive mechanisms, via the biosynthesis of a cascade of antioxidants. Antioxidant defense system enhancement is an important strategy to scavenge ROS by antioxidant enzyme such as ascorbate peroxidase (APX), ascorbate reductase (AR), catalase (CAT), glutathione reductase (GR), glutathione peroxidase (GPX), and superoxide dismutase (SOD) and with non-enzymatic antioxidants such as ascorbate (AsA), glutathione (GSH), carotenoids, flavanones, and anthocyanins (Hasanuzzaman et al. 2014).

Egypt presents a typical example of the drought problem faced in some arid regions. There is a critical need to balance water availability, water requirements, and water consumption. Thus, water conserving is becoming a crucial consideration for agriculture. To bridge the gap between different crop production and consumption, increasing and exploiting production of crops in these areas are necessary. So, application of osmoprotectants, as trehalose was found to extent positive effect of plant growth which overcomes the harmful effect of some environmental stress such as drought. Trehalose (Tre) is a non-reducing disaccharide of glucose that stabilizes biological structures and macromolecules such as membrane lipids and proteins during abiotic stresses (Luo et al. 2010). Exogenous treatment of trehalose is transported by leaf or root cells to different cells and displays significant roles as osmoprotectant (Luo et al. 2010). Trehalose is distributed widely among different biological systems: bacteria, fungi, and lower and higher plants (Elbein et al. 2003). During a biotic stress, trehalose does not function directly in alleviation of stress; it may act as a signal molecule. Thus the aim of the present work was to improve drought tolerance of quinoa plants grown under newly reclaimed sandy soil by exogenous application of different concentrations of trehalose.

\section{Materials and methods}

\section{Plant material and growth conditions}

A field experiment was conducted at the Experimental Station of National Research Centre, Nubaria district Beheira Governorate, Egypt, during two successive seasons of 2013/2014 and 2014/2015. The soils of both experimental sites were reclaimed sandy soil where mechanical and chemical analysis is reported in Table 1 according to Chapman and Pratt (1978).

Seeds of quinoa (Chenopodium quinoa Willd.) Quinoa 1 cultivar was obtained from Agricultural Research Centre Giza, Egypt. The experimental design was split-plot with four replications. The main plots were devoted to the irrigation treatments, while the trehalose concentrations treatments were randomly occupied the sub-plots. Quinoa seeds were sown on October in both seasons at the rate of $3 \mathrm{~kg} /$ faddan (one faddan $=0.42 \mathrm{ha}$ ) in rows $3.5 \mathrm{~m}$ long, and the distance between rows was $20 \mathrm{~cm}$ apart. Plot area was $10.5 \mathrm{~m}^{2}$ (3.0 m in width and $3.5 \mathrm{~m}$ in length). The recommended agricultural practices of growing quinoa were applied. Pre-sowing $150 \mathrm{~kg} /$ feddan of calcium super-phosphate $\left(15.5 \% \mathrm{P}_{2} \mathrm{O}_{5}\right)$ was applied to the soil. Nitrogen was applied after emergence in the form of ammonium nitrate $33.5 \%$ at a rate of $75 \mathrm{~kg} /$ feddan in five equal doses before the 1st, 2nd, 3rd, 4 th, and 5th irrigation. Potassium sulfate $(48.52 \%$ $\mathrm{K}_{2} \mathrm{O}$ ) was added in two equal doses of $50 \mathrm{~kg} /$ feddan, before the 1st and 3rd irrigations. Irrigation was carried out using the new sprinkler irrigation system where water was added every 5 days. Trehalose foliar treatment consisted of three levels of trehalose namely $0 \mathrm{mM}$ (control), $0.1 \mathrm{mM}$, and $0.5 \mathrm{mM}$ considered as Tre ${ }_{0}$, $\mathrm{Tre}_{1}$, and $\mathrm{Tre}_{2}$ respectively. Drought stress including normal irrigation $\left(D_{0}\right)$ and skipping two irrigation times $\left(D_{1}\right)$. Different trehalose treatments were carried out twice, where plants were sprayed after 30 and 45 days from sowing. Skipping the irrigation at 50 and 60 days after sowing. Plant samples were taken after 75 days from sowing for estimation of some biochemical parameters in leaves of plant such as carbohydrate constituents (glucose, sucrose, trehalose, total soluble sugars, and starch), proline, total free amino acid, phenolic contents, as well as hydrogen 
Table 1 Mechanical and chemical analysis of the experimental soil sites

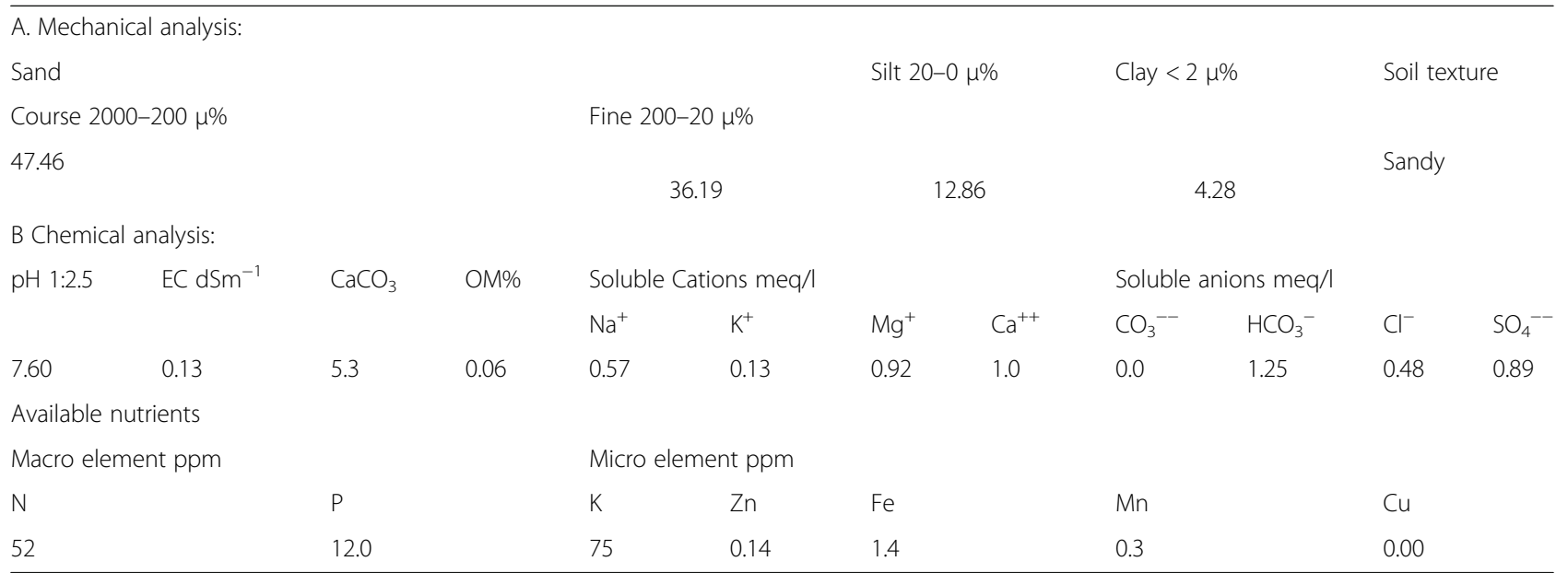

peroxide content $\left(\mathrm{H}_{2} \mathrm{O}_{2}\right)$, lipid peroxidation lipoxygenase (LOX), and antioxidant enzymes (superoxide dismutase (SOD), catalase (CAT), polyphenol oxidase (POX), and ascorbate peroxidase (APX)).

\section{Biochemical analysis Determination of glucose}

Glucose estimations were performed using a modification of O-toluidine procedure (Feteris 1965). Sugars were extracted by overnight submersion of dry tissue in $80 \%(v / v)$ ethanol at $25{ }^{\circ} \mathrm{C}$ with periodic shaking. A $1.0 \mathrm{ml}$ aliquot of the alcoholic extract was heated with $5.0 \mathrm{ml} \mathrm{O}$-toluidine reagent $(60 \mathrm{ml} \mathrm{O}$-toluidine and $2.0 \mathrm{~g}$ thiourea made to $1 \mathrm{~L}$ with glacial acetic acid) for $15 \mathrm{~min}$ at $97^{\circ} \mathrm{C}$. Absorbance was measured at $630 \mathrm{~nm}$.

\section{Determination of sucrose}

Sucrose contents were determined by first degrading reactive sugars present in $0.1 \mathrm{ml}$ extracts with $0.1 \mathrm{ml}$ 5.4 $\mathrm{N} \mathrm{KOH}$ at $97{ }^{\circ} \mathrm{C}$ for $10 \mathrm{~min}$ (Handel 1968). Three milliliters of freshly prepared anthrone reagent were then added to the cooled reaction product, and the mixture was heated at $97{ }^{\circ} \mathrm{C}$ for $5 \mathrm{~min}$, cooled, and read at $620 \mathrm{~nm}$.

\section{Determination of trehalose}

Trehalose content in the quinoa leaves was determined following the method described by Li et al. (2014) with some modifications. The leaves (1.0 g) were homogenized in $5 \mathrm{ml}$ of $80 \%(v / v)$ hot ethanol and centrifuged at $11,500 \times g$ for $20 \mathrm{~min}$. The supernatants were dried at $80{ }^{\circ} \mathrm{C}$ followed by resuspension in $5 \mathrm{ml}$ distilled water. The solution $(100 \mu \mathrm{l})$ was mixed with $150 \mu \mathrm{l} 0.2 \mathrm{~N}$ $\mathrm{H}_{2} \mathrm{SO}_{4}$ and boiled at $100{ }^{\circ} \mathrm{C}$ for $10 \mathrm{~min}$ to hydrolyze any sucrose or glucose-1-phosphate, etc., and then chilled on ice. $\mathrm{NaOH}(0.6 \mathrm{~N}, 150 \mu \mathrm{l})$ was added to the above mixture and boiled for $10 \mathrm{~min}$ to destroy reducing sugars, and then chilled again. To the above mixture, $2.0 \mathrm{ml}$ of anthrone reagent $(0.2 \mathrm{~g}$ anthrone per $100 \mathrm{ml}$ of $95 \%$ $\mathrm{H}_{2} \mathrm{SO}_{4}$ ) was added and boiled for 10 min to develop a color, and then chilled again. The absorbance was recorded at $630 \mathrm{~nm}$, and trehalose concentration was calculated as micromoles per gram FW using a standard curve developed with commercial trehalose.

\section{Determination of total soluble sugars}

Total soluble sugars (TSS) were extracted by overnight submersion of dry tissue in $10 \mathrm{ml}$ of $80 \%(v / v)$ ethanol at $25{ }^{\circ} \mathrm{C}$ with periodic shaking, and centrifuged at $600 \times g$. The supernatant was evaporated till completely dried then dissolved in a known volume of distilled water to be ready for determination of soluble carbohydrates (Homme et al. 1992). TSS were analyzed by reacting of $0.1 \mathrm{ml}$ of ethanolic extract with $3.0 \mathrm{ml}$ freshly prepared anthrone (150 mg anthrone $\left.+100 \mathrm{ml} \mathrm{72 \%} \mathrm{H}_{2} \mathrm{SO}_{4}\right)$ in boiling water bath for $10 \mathrm{~min}$ and reading the cooled samples at $625 \mathrm{~nm}$ using Spekol SpectrocololourimeterVEB Carl Zeiss (Yemm and Willis 1954).

\section{Determination of starch}

For starch measurement, the insoluble fraction remaining after ethanolic extraction of soluble sugars was resuspended in $2 \mathrm{ml}$ of $2.5 \mathrm{M} \mathrm{NaOH}$ and boiled for $5 \mathrm{~min}$. After cooling the solution, $\mathrm{pH}$ was adjusted to $\mathrm{pH} 4.5$ with $2 \mathrm{M} \mathrm{HCl}$, and the resulting gelatinized starch was hydrolyzed $10 \mathrm{~min}$ at $50{ }^{\circ} \mathrm{C}$ with buffered (0.1 M sodium acetate buffer, $\mathrm{pH} 4.5)$. After this process, starch was measured as reducing sugars by Nelson's method (Nelson, 1944) and expressed in maltose equivalents.

\section{Determination of proline}

Proline was assayed according to the method described by Bates et al. (1973). Then, $2.0 \mathrm{ml}$ of proline extract, 
$2.0 \mathrm{ml}$ of acid ninhydrin, and $2.0 \mathrm{ml}$ of glacial acetic acid were added and incubated for $1 \mathrm{~h}$ in a boiling water bath followed by an ice bath. The absorbance was measured at $520 \mathrm{~nm}$ using Spekol Spectrocololourimeter VEB Carl Zeiss. A standard curve was obtained using a known concentration of authentic proline.

\section{Determination of free amino acids}

Free amino acid content was extracted according to the method described by Vartainan et al. (1992). Free amino acid was determined with the ninhydrin reagent method (Yemm and Cocking 1955). Further, $1.0 \mathrm{ml}$ acetate buffer ( $\mathrm{pH} 5.4)$ and $1.0 \mathrm{ml}$ chromogenic agent were added to $1.0 \mathrm{ml}$ free amino acid extraction. The mixture was heated in boiling water bath for 15 min. After cooled in tap water, $3 \mathrm{ml}$ ethanol $(60 \% \mathrm{v} / \mathrm{v})$ was added. The absorbance at $570 \mathrm{~nm}$ was then monitored using Spekol Spectrocololourimeter VEB Carl Zeiss.

\section{Determination of phenolic contents}

A known weight of the fresh samples was taken and extracted with $85 \%$ cold methanol $(v / v)$ for three times at $0{ }^{\circ} \mathrm{C}$. The combined extracts were collected and made up to a known volume with cold methanol. And then $0.5 \mathrm{ml}$ of the extraction was added to $0.5 \mathrm{ml}$ Folin reagent, shaked, and allowed to stand for $3 \mathrm{~min}$. Then $1 \mathrm{ml}$ of saturated sodium carbonate was added to each tube followed by distilled water shaken and allowed to stand for $60 \mathrm{~min}$. The optical density was determined at wave length of $725 \mathrm{~nm}$ using spectrophotometer as described by Danil and George (1972).

\section{Determination of lipid peroxidation}

The level of lipid peroxidation was measured by determining the levels of malondialdehyde (MDA) content using the method of Hodges et al. (1999). A sample (200 mg) was homogenized in $10 \mathrm{ml}$ of $5 \%$ trichloroacetic acid (TCA). The homogenate was centrifuged at $15,000 \times g$ for $10 \mathrm{~min}$ to $2.0 \mathrm{ml}$ aliquot of the supernatant $4.0 \mathrm{ml}$ of $0.5 \%$ thiobarbituric acid (TBA) in 20\% TCA was added. The mixture was heated at $95{ }^{\circ} \mathrm{C}$ for $30 \mathrm{~min}$ and then quickly cooled in an ice bath and centrifuged at $10,000 \times g$ for $10 \mathrm{~min}$, then the absorbance of supernatant was recorded at $532 \mathrm{~nm}$ by spectrophotometer (Shimadzu). The value for non-specific absorption at $600 \mathrm{~nm}$ was subtracted. The MDA content was calculated using its absorption coefficient of $155 \mathrm{nmol}^{-1} \mathrm{~cm}^{-1}$ and expressed as nmol (MDA) $\mathrm{g}^{-1}$ fresh weight.

\section{Assay of enzymes activities}

Enzyme extracts were collected following the method described by Chen and Wang (2006). Leaf tissues were homogenized in ice-cold phosphate buffer $(50 \mathrm{mM}, \mathrm{pH}$ 7.8), followed by centrifugation at $8000 \mathrm{rpm}$ and $4-\mathrm{C}$ for
$15 \mathrm{~min}$. The supernatant was used immediately to determine the activities of enzymes.

Lipoxygenase activity Lipoxygenase (LOX) (EC 1.13.11.12) activity was estimated according to the method of Doderer et al. (1992) by monitoring the increase in absorbance at $234 \mathrm{~nm}$ using linoleic acid as a substrate. The activity was calculated using the extinction coefficient $\left(25 \mathrm{mM}^{-1} \mathrm{~cm}^{-1}\right)$ and express as units (1 nmol of substrate oxidized per minute) per $\mathrm{mg}$ protein.

Peroxidase activity Peroxidase (POX) (EC 1.11.1.7) activity was assayed by the method of Kumar and Khan (1982). The reaction mixture used for estimating the peroxidase enzyme (POX) contained $2 \mathrm{ml}$ of $0.1 \mathrm{M}$ phosphate buffer ( $\mathrm{pH}$ 6.8), $1 \mathrm{ml}$ of $0.01 \mathrm{M}$ pyrogallol, $1 \mathrm{ml}$ of $0.005 \mathrm{M} \mathrm{H}_{2} \mathrm{O}_{2}$, and $0.5 \mathrm{ml}$ of the enzyme extract. The solution was incubated for $5 \mathrm{~min}$ at $25{ }^{\circ} \mathrm{C}$ after which the reaction was terminated by adding $1 \mathrm{ml}$ of $2.5 \mathrm{~N} \mathrm{H}_{2} \mathrm{SO}_{4}$. The amount of purpurogallin formed was determined by measuring the absorbance at $420 \mathrm{~nm}$ against a reagent blank prepared by adding the extract after the addition of $2.5 \mathrm{~N} \mathrm{H}_{2} \mathrm{SO}_{4}$ at the zero time.

Superoxide dismutase activity Superoxide dismutase (SOD) (EC 1.12.1.1) activity was spectrophotometrically assayed at $560 \mathrm{~nm}$ by nitro-blue-tetrazolium (NBT) reduction method (Chen and Wang 2006). The reaction mixture $(3 \mathrm{ml})$ contained $150 \mu$ riboflavin $(13 \mu \mathrm{M})$, $2.5 \mathrm{ml}$ methionine $(13 \mu \mathrm{M}), 250 \mu \mathrm{NBT}(63 \mu \mathrm{M}), 50 \mu$ phosphate buffer $(50 \mathrm{mM}, \mathrm{pH} 7.8)$, and $50 \mu$ enzyme extract. One unit of SOD activity was defined as the amount of enzyme protein required for inhibition of the $50 \%$ reduction of NBT.

Catalase activity Catalase (CAT) (EC 1.11.1.6) activity was determined spectrophotometrically by following the decrease in absorbance at $240 \mathrm{~nm}$ (Chen and Wang 2006). The mixture $(3 \mathrm{ml})$ contained $1.9 \mathrm{ml}$ phosphate buffer (50 mM, pH 7.0), $100 \mu$ l enzyme extract, and $1 \mathrm{ml}$ $0.3 \% \mathrm{H}_{2} \mathrm{O}_{2}$. The reaction was initiated by adding enzyme extract. One unit of CAT activity was defined as the 0.01 deduction in absorbance at $240 \mathrm{~nm}$ per minute. The enzyme activities were calculated by Kong et al. (1999).

Ascorbate peroxidase activity Ascorbate peroxidase (EC 1.11.1.11) activity was determined as described by Nakano and Asada (1987). The reaction mixture (1 ml) contained $50 \mathrm{mM}$ potassium phosphate ( $\mathrm{pH} 7.0), 1.2 \%$ sucrose, $1 \mathrm{mM}$ hydrogen peroxide, $0.5 \mathrm{mM}$ ascorbate, and $10 \mathrm{mM}$ 3-aminotriazole (an inhibitor of catalase). The hydrogen peroxide-dependent oxidation of ascorbate was 
followed by monitoring the decrease in absorbance at $290 \mathrm{~nm}$, using the extinction coefficient of $2.8 \mathrm{mM} \mathrm{cm}^{-1}$.

\section{Statistical analysis}

The analysis of variance procedure of split-plot design according to Snedecor and Cochran (1990), treatments means were compared using Duncan (1955) test at 5\% of probability. Combined analysis of the two growing seasons was carried out.

\section{Results}

\section{Carbohydrate constituents}

Glucose, sucrose, trehalose, TSS, and starch contents of quinoa leaves in response to treatment of quinoa plants with different concentrations of trehalose under drought stress are presented in Fig. 1. Data clearly show that skipping irrigation at 50 and 60 days after sowing increased significantly glucose, trehalose, total soluble sugars, and starch contents of quinoa leaves as compared with those irrigated normally (control plants); meanwhile, sucrose contents decreased. More accumulation of the tested organic solutes of leaves of the trehalose-treated plant in both normal irrigated and drought stressed quinoa plants.

\section{Changes in proline and free amino acid contents}

Data clearly show that treatments with different concentrations of trehalose on quinoa plant under normal and drought stress are presented in Fig. 2. Skipping two irrigation times at 50 and 60 days after sowing caused significant increases in proline and free amino acids of quinoa leaves as compared with normal irrigated plants (control). Meanwhile, foliar treatment of different concentrations of trehalose $0.1 \mathrm{mM}$ and $0.5 \mathrm{mM}$ (Tre ${ }_{1}$ or $\mathrm{Tre}_{2}$ ) decreased significantly and gradually proline and free amino acid contents.

\section{Changes in phenolic contents}

Data presented in Fig. 2 showed the effect of different concentrations of trehalose treatment on quinoa plant under drought stress. Drought stress (D1) caused significant increases in phenolic contents relative to control plant (D0 Tre0). Trehalose foliar treatment with

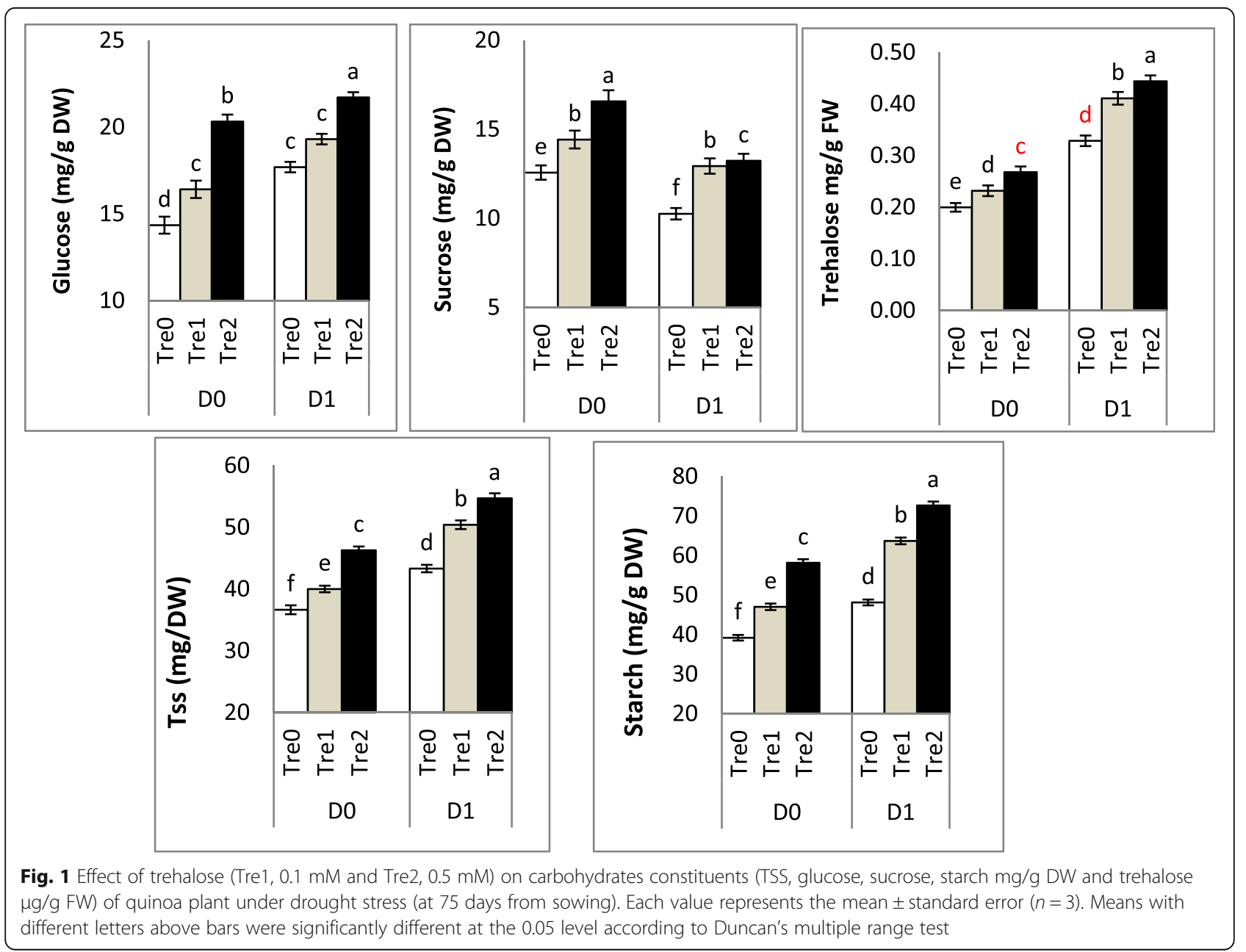




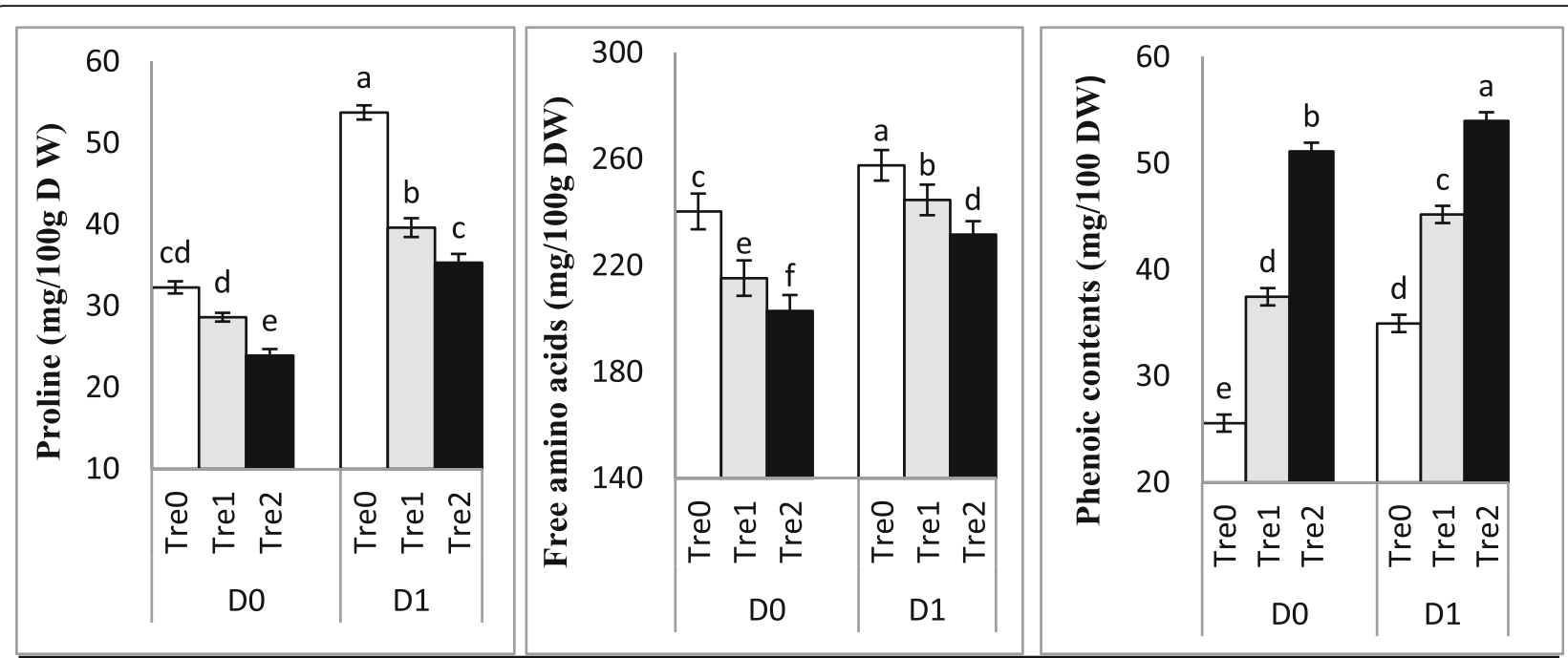

Fig. 2 Effect of trehalose (Tre1, $0.1 \mathrm{mM}$ and Tre2, $0.5 \mathrm{mM}$ ) on proline, free amino acids and phenolic contents ( $\mathrm{mg} / 100 \mathrm{~g}$ DW) of quinoa plant under drought stress (at 75 days from sowing). Each value represents the mean \pm standard error $(n=4)$. Means with different letters above bars were significantly different at the 0.05 level according to Duncan's multiple range test

different concentrations (Tre1 and Tre2) in normal irrigation caused more significant increases in phenolic content as compared with control plant (D0 Tre0). Then, $0.5 \mathrm{mM}$ trehalose was more effective than $0.1 \mathrm{mM}$ trehalose in improving phenolic contents.

\section{Hydrogen peroxide}

The level of hydrogen peroxide $\left(\mathrm{H}_{2} \mathrm{O}_{2}\right)$ upon drought stress is presented in (Fig. 3), $\mathrm{H}_{2} \mathrm{O}_{2}$ level sharply increased in quinoa leaves. The $\mathrm{H}_{2} \mathrm{O}_{2}$ level increased by $43 \%$ in the D1 drought stress plants compared with the control plants (D0). Trehalose foliar treatment decreased significantly the level of $\mathrm{H}_{2} \mathrm{O}_{2}$ in the normal irrigated plants and drought compared with the corresponding control.

\section{Lipid peroxidation}

The effect of trehalose foliar treatment on quinoa plants grown under drought stress are presented in (Fig. 3). Drought stress induced oxidative damage, assessed by increasing in lipid peroxidation in the tested quinoa plant (Fig. 3) as compared with unstressed control

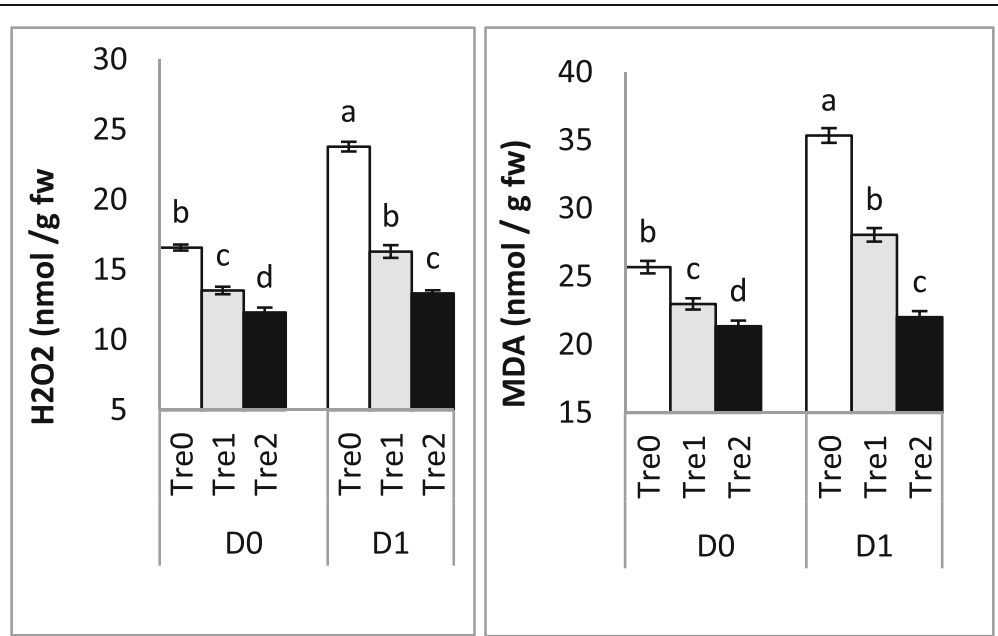

Fig. 3 Effect of trehalose (Tre1, $0.1 \mathrm{mM}$ and Tre2, $0.5 \mathrm{mM}$ ) on H2O2, MDA contents ( $\mathrm{n} \mathrm{mol} / \mathrm{g} \mathrm{fw}$ ) of quinoa plant under drought stress (at 75 days from sowing) Each value represents the mean \pm standard error $(n=3)$. Means with different letters above bars were significantly different at the 0.05 level according to Duncan's multiple range test 
plants. Moreover, gradual decreases in lipid peroxidation by trehalose foliar treatment with different concentrations (Tre1 and Tre2) as compared with the corresponding control in normal and stressed plants.

\section{Enzyme activities}

Lipoxygenase activity

Lipoxygenase activities in quinoa leaves were increased by $141 \%$ under drought stress (D1) compared to non-stress control (D0) Fig. 4. In non-stressed plants, trehalose treatment had no significant effect on LOX activity. Regarding to trehalose treatment combined with drought treatment (Fig. 4), LOX enzyme activity decreased gradually and significantly as compared with their corresponding control.

\section{Antioxidant enzymes}

Activities of various antioxidant enzymes in droughtstressed and trehalose foliar-treated plants are presented in (Fig. 4). Drought stress by skipping irrigation caused significant increases in SOD, POX, and APX, but CAT activity significant decreased. Trehalose foliar treatment with different concentrations Tre1 and Tre2 increased plant tolerance to stress via significant increases in SOD,
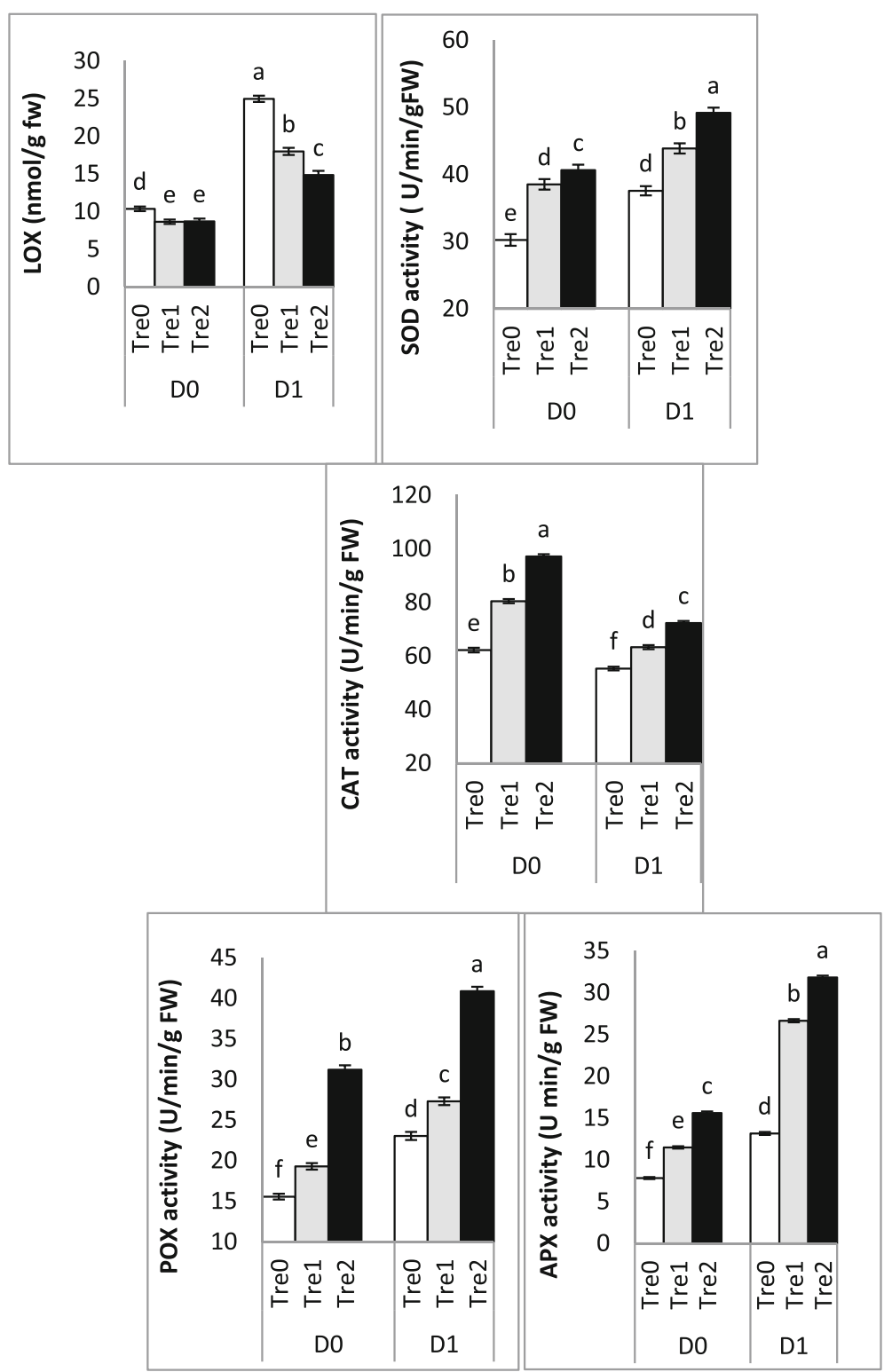

Fig. 4 Effect of trehalose (Tre1, $0.1 \mathrm{mM}$ and Tre2, $0.5 \mathrm{mM}$ ) on LOX activity (nmol/g FW) and antioxidant enzyme activities (SOD, CAT, POX, and APX) (U/min/gFW) of quinoa plant under drought stress (at 75 days from sowing); each value represents the mean \pm standard error $(n=3)$. Means with different letters above bars were significantly different at the 0.05 level according to Duncan's multiple range test 
CAT, POX, and APX activities as compared with D0 and D1. Further, $0.5 \mathrm{mM}$ trehalose was more effective than $0.1 \mathrm{mM}$ in increasing enzyme activities of quinoa plants.

\section{Discussion}

\section{Carbohydrates constituents}

Regarding carbohydrates constituents of quinoa leaves treated with trehalose different concentrations and grown under drought stress (Fig. 1). Data show accumulation of different carbohydrates constituents as glucose sucrose, trehalose, TSS, and starch contents. Although accumulation of high soluble sugar levels have also been demonstrated in shoots of different plant species under drought stress conditions (Bakry et al. 2012 and Dawood and Sadak 2014). Increased levels of soluble sugars in drought-stressed plants may help in turgor upkeeping and cellular membrane stabilization (Hosseini et al., 2014). This increases of soluble sugars is a response of plants to drought stress that has been widely reported despite the decrease in net $\mathrm{CO}_{2}$ assimilation rate (Murakeozy et al. 2003). In addition, soluble sugars may act as ROS scavengers to improve membrane stabilization (Hosseini et al. 2014).

During plant development, trehalose could play an important role in regulating carbohydrate allocation, as Tre acting as soluble sugars in quinoa leaves and its function is an osmoprotectant under water deficit-induced stresses. The present study show that in quinoa leaves, trehalose accumulation is concomitant with increasing sucrose level under normal and skipped irrigation (Fig. 1). Garg et al. (2007) confirmed these obtained results. The indirect effect of Tre on carbohydrate metabolism may be via conversion and utilization of other sugars and interfering with photosynthetic capacity (Ranwala and Miller 2009). Application of trehalose induced an additive stimulatory effect on the accumulation of trehalose contents in the drought plants. These results are in good agreements with those obtained by $\mathrm{Ma}$ et al. (2013). The improving effect of trehalose may be due to its physicochemical properties that stabilize dehydrated enzymes, proteins, and lipid membranes, as well as protect structures from damage during desiccation (Fernandez et al. 2010). Also, Tre involved in gene detoxification and response to stress as it acts as gene elicitor (Bae et al. 2005).

In the present study, the starch content increased in quinoa plant normal irrigated and drought stressed in response to trehalose corresponding control and consequence of trehalose accumulation (Fig. 1). Bae et al. (2005) reported that in Arabidopsis thaliana seedlings, starch was threefold greater in trehalose-treated plants than in the control. The increase in the level of sucrose, trehalose, and total soluble sugar (Fig. 1) may be linked to the changes in starch content. Accumulation of starch in quinoa leaves may be a protective mechanism as it is an important component of plant cells and its increases in leaves as a reserve form of carbon (Mishra and Prakash 2010). The increases in starch by trehalose treatment might be due to increased activity of ADP-glucose pyrophosphorylase (AGPase), a major enzyme controlling starch synthesis in Arabidopsis (Bae et al. 2005).

\section{Changes in proline and free amino acids}

In the present work, water-deficient stress caused significant increases of proline and free amino acids, whereas decreased by trehalose application (Fig. 2). Accumulation of compatible osmolytes high concentrations causing the osmotic adjustment in plants under drought stress. Proline has vital roles in osmotic adjustment, stabilization, and protection of enzymes, proteins, and membranes (Ashraf and Foolad 2007) from damaging effects of drought-osmotic stresses. Also, reducing oxidation of lipid membranes (Demiral and Türkan 2004). Trehalose addition with drought stress reduced proline and free amino acids levels in quinoa plant (Fig. 2). Prevention of extra proline biosynthesis due to exogenous trehalose addition under drought stress suggests that trehalose prevented quinoa seedlings from adverse effects of drought stress by other means so that the studied quinoa seedlings did not need to increase the proline levels further. These results are corroborated to previous studies (Alam et al. 2014 and Abdallah et al. 2016).

\section{Phenolic contents}

Figure 2 shows that drought stress and/or trehalose foliar treatments enhanced the phenolic content of quinoa leaves. Increase in phenol contents in different tissues under osmotic stress have been reported in many plants (Rady et al. 2011, Dawood and Sadak 2014 and Sadak 2016a, b). These increases may be due to total phenols role that play a significant mechanism in regulation of plant metabolic processes and consequently overall plant growth (Abdallah et al. 2015). Moreover, phenols act as a substrate for many antioxidant enzymes; so, it mitigates the drought stress injuries (Bakry et al. 2012). Another mechanism underlying the antioxidative properties of phenolic compounds is the ability of phenols to decrease membrane fluidity (Sadak 2016b). In addition, the antioxidant role of phenolic compounds as free radical scavenger through their reactivity as electron or hydrogen donor, to stabilize and delocalize the unpaired electron, and from their role as transition metal ions chelater (Huang et al. 2005). The improvement in the role of trehalose might be due to its signaling function, via different metabolic pathways induction and induce the production of various substances, preferably operating under stress (Alam et al. 2014). 


\section{$\mathrm{H}_{2} \mathrm{O}_{2}$ content and lipid peroxidation}

As shown in Fig. 3, quinoa plants responded to drought stress by inducing marked increases in $\mathrm{H}_{2} \mathrm{O}_{2}$ and MDA contents. Under stress, accumulation of ROS including $\mathrm{H}_{2} \mathrm{O}_{2}$ caused oxidative damage in plants and produced MDA, the potential biomarker of membrane lipid peroxidation in the cellular environment (Abdelhamid et al. 2013; Orabi and Sadak 2015; El Bassiouny et al. 2015). Drought stress caused changes in physical membrane organization and modification in the lipid matrix of the plasma membrane. In addition, it caused marked increases in MDA and $\mathrm{H}_{2} \mathrm{O}_{2}$ levels in different plant species including rapeseed and mustard may be due to inadequate induction of antioxidant system as mentioned by Hossain et al. (2013). Similar results of increased $\mathrm{H}_{2} \mathrm{O}_{2}$ and MDA contents under stress were obtained by El Bassiouny et al. (2015) on wheat, Dawood and Sadak (2014) on canola, and Mostafa et al. 2015) on rice plant. However, trehalose foliar treatment prior to drought stress resulted in lower $\mathrm{H}_{2} \mathrm{O}_{2}$ production, and reduced MDA content, which may be achieved via trehalose-mediated direct ROS scavenging, antioxidative mechanism involved in eliminating ROS, or stabilizing of membrane. Exogenous trehalose also reduced the levels of $\mathrm{H}_{2} \mathrm{O}_{2}$ and MDA in rice seedlings under salt stress, respectively (Mostafa et al. 2015).

\section{Lipoxygenase activity}

Lipoxygenase (LOX) activities increased in quinoa plants subjected to water deficiency (Fig. 4), which concomitant with higher MDA levels (Fig. 3). In addition, increased LOX activity might have contributed to the lipid peroxidation of membrane lipids and thereby significantly participate to the oxidative damage in water-deficient plant. Increased LOX activity is responsible for oxidation of polyunsaturated fatty acids and thus enhances lipid peroxidation under stress conditions (Sánchez-Rodríguez et al. 2012). The beneficial roles of Tre in drought-affected quinoa plants were observed as those treatments reduced oxidative stress (decreased $\mathrm{H}_{2} \mathrm{O}_{2}$ reduced LOX and lowered MDA levels; Figs. 3 and 4), compared to Tre-untreated drought-affected plants. These results are in agreement with Nounjan and Theerakulpisut (2012), Ma et al. (2013), and Liu et al. (2013); they confirmed that exogenous application of Tre was effective in reducing oxidative stress of different plants in different abiotic stresses.

\section{Antioxidant enzymes activities}

Plant posses' efficient system for scavenging ROS. Antioxidative enzymes are not part of this system but are key elements in the defense mechanisms. Activities of antioxidant enzymes of plants under stress show many changes (Abdelhamid et al. 2013). Superoxide dismutase, catalase, ascorbate peroxidase, and peroxidase are of enzymes that are responsible for ROS-scavenging. Drought exhibited increased SOD or POX and APX activities in quinoa leaves as compared to normal irrigated plants (Fig. 4). These results are in agreement with (Abdelgawad et al. 2014). Higher levels of enzyme activities in the quinoa plant under water deficiency may be due to its resistance. $\mathrm{NAD}^{+}$recovering and $\mathrm{CO}_{2}$ fixation at the Calvin cycle decrease under drought stress cause damage to cell membrane due to the increases of free radicals. Adverse environmental stresses increase catalase and ascorbate peroxidase activities in several cycles of physiological processes. At stress conditions, higher content of hydrogen peroxide is detoxified by catalase and glutathione peroxidase (Dat et al. 2000). Plant tolerance to harmful free radicals increase by ascorbate peroxidase and catalase activities increases (Jin et al. 2006). Superoxide dismutase (SOD) is the first defense enzyme that converts superoxide to $\mathrm{H}_{2} \mathrm{O}_{2}$, which can be scavenged by catalase (CAT) and different classes of peroxidases (POX) and ascorbate peroxidase. These results are in agreement with the results observed by El-Bassiouny and Sadak (2015), Sadak and Orabi (2015), and Sadak and Abdelhamid (2015).

Foliar treatment of trehalose increased tolerance to stress by the increase in CAT, SOD, POX, and APX activities. Abdallah et al. (2016) confirmed these results. Under drought stress, Tre treatment improve SOD activity (Nounjan and Theerakulpisut 2012). However, Nounjan et al. (2012) also confirmed Tre major role in $\mathrm{O}_{2}{ }^{-}$scavenging directly than modulating SOD activity. Although, CAT is one of the most important enzyme of antioxidant system having the highest turnover rates among all enzymes (Garg and Manchanda 2009). However, enhanced CAT activity in Tre-pretreated plants represents an efficient $\mathrm{H}_{2} \mathrm{O}_{2}$ scavenging mechanism contributing to tolerance to water stress-induced oxidative stress (Mostafa et al. 2015). CAT, a peroxisomal enzyme, has a lower affinity for $\mathrm{H}_{2} \mathrm{O}_{2}$ and, therefore, is regarded as a bulk remover of excess $\mathrm{H}_{2} \mathrm{O}_{2}$ produced under stress conditions.

\section{Conclusion}

Osmolytes as Tre improved drought tolerance of quinoa plant via increasing formation of osmoprotectant compounds as glucose, trehalose, total soluble sugars, proline, and free amino acids. In addition to enhancing antioxidant enzyme activities. On the other hand, MDA and $\mathrm{H}_{2} \mathrm{O}_{2}$ contents decrease.

\section{Acknowledgements}

Not applicable.

Funding

Not applicable. 


\section{Availability of data and materials}

Not applicable.

\section{Authors' contributions}

All authors share in every step of this work and all of them contribute in writing the manuscript. All authors read and approved the final manuscript.

\section{Ethics approval and consent to participate}

Not applicable.

\section{Consent for publication}

Not applicable.

\section{Competing interests}

The authors declare that they have no competing interests.

\section{Publisher's Note}

Springer Nature remains neutral with regard to jurisdictional claims in published maps and institutional affiliations.

Received: 27 June 2018 Accepted: 7 December 2018

Published online: 17 January 2019

\section{References}

Abdallah MMS, Abdelgawad ZA, El-Bassiouny HMS (2016) Alleviation of the adverse effects of salinity stress using trehalose in two rice varieties. S Afr J Bot 103:275-282

Abdallah MMS, El-Bassiouny HMS, Bakry AB, Sadak MS (2015) Effect of arbuscular mycorrhiza and glutamic acid on growth, yield, some chemical composition and nutritional quality of wheat plant grown in newly reclaimed Sandy soil. RJPBCS 6(3):1038-1054

Abdelgawad ZA, Khalafa allah AA, Abdallah MM (2014) Impact of methyl jasmonate on antioxidant activity and some biochemical aspects of maize plant grown under water stress condition. Agric Sci 5:1077-1088

Abdelhamid MT, Sadak MS, Schmidhalter U, El-Saady A (2013) Interactive effects of salinity stress and nicotinamide on physiological and biochemical parameters of faba bean plant. Acta Biol Colomb 18(3):499-510

Alam M, Nahar K, Hasanuzzaman M, Fujita M (2014) Trehalose-induced drought stress tolerance: A comparative study among different Brassica species. Plant Omics J 7(4):271-283

Ashraf M, Foolad MR (2007) Roles of glycine betaine and proline in improving lant abiotic stress tolerance. Environ Exp Bot 59:206-216

Bae H, Herman E, Bailey B, Bae HJ, Sicher R (2005) Exogenous trehalose alters Arabidopsis transcripts involved in cell wall modification, abiotic stress, nitrogen metabolism and plant defense. Physiol Plant 125:114-126

Bakry BA, El-Hariri DM, Sadak MS, El-Bassiouny HMS (2012) Drought stress mitigation by foliar application of salicylic acid in two linseed varieties grown under newly reclaimed Sandy soil. J Appl Sci Res 8(7):3503-3514

Bates LS, Waldan RP, Teare LD (1973) Rapid determination of free proline under water stress studies. Plant Soil 39:205-207

Bhargava A, Shukla S, Ohri D (2007) Genetic variability and interrelation ship among various morphological and quality traits in quinoa (Chenopodium quinoa Willd.). Field Crop Res 101:104-116

Chapman HO, Pratt PE (1978) Methods of analysis for soils, plants and water. Division of Agriculture Sciences University California, Berkley, pp 5-6

Chen JX, Wang XF (2006) Plant physiology experimental guide. Higher Education Press, Beijing, pp 24-25:55-56

Danil AD, George CM (1972) Peach seed dormancy in relation to endogenous inhibitors and applied growth substances. J Amer Soc Hort Sci 17:621-624

Dat J, Vandenabeele S, Vranova E, Van Montagu M, Inzé D, Van Breusegem F (2000) Dual action of the active oxygen species during plant stress responses. Cell Mol Life Sci 57:779-795

Dawood MG, Sadak MS (2014) Physiological role of glycinebetaine in alleviating the deleterious effects of drought stress on canola plants (Brassica napus L.). Middle East J Agric Res 3(3):638-644

Demiral T, Türkan I (2004) Does exogenous glycine betaine affect antioxidative system of rice seedlings under $\mathrm{NaCl}$ treatment? J Plant Physiol 161:108

Demirevska K, Simova-Stoilova L, Fedina I, Georgieva K, Kunert K (2010) Response of oryzacystatin I transformed tobacco plants to drought, heat and light stress. J Agron Crop Sci 196:90-99
Doderer A, Kokkelink I, van der Veen S, Valk B, Schram A, Douma A (1992) Purification and characterization of two lipoxygenase isoenzymes from germinating barley. Biochim Biophys Acta 112:97-104

Duncan DB (1955) Multiple range and multiple F-tests. Biometrics 11:1-42

El Bassiouny HMS, Abd Allah MMS, Rady MM, Gaballah MS, El-Sebai TN (2015) Role of blue-green algae, glutathione and salicylic acid on the oxidative defense systems of wheat plant grown in saline soil. Int J PharmTech Res 8(10):18-31

El-Bassiouny HMS, Sadak MS (2015) Impact of foliar application of ascorbic acid and a-tocopherol on antioxidant activity and some biochemical aspects of flax cultivars under salinity stress. Acta biol Colomb 20(2):209-222

Elbein AD, Pan YT, Pastuszak I, Carroll D (2003) New insights on trehalose: a multifunctional molecule. Glycobiology 13(4):17r-27r ISSN 0959-6658

Fernandez O, Béthencourt L, Quero A, Sangwan RS, Clément C (2010) Trehalose andplant stress responses: friend or foe? Trends Plant Sci 15:409-417

Feteris AW (1965) A serum glucose method without protein precipitation. Am J Medical Technol 31:17-21

Fuentes FF, Bazile D, Bhargava A, Martínez EA (2012) Implications of farmers' seed exchanges for on-farm conservation of quinoa, as revealed by its genetic diversity in Chile. J Agric Sci 150:702-716

Garg AK, Ranwala AP, Miller WB, Wu RJ (2007) HPLC analysis of trehalose and other soluble carbohydrates from the leaf tissue of Indica and Japonica rice varieties. Rice Genetics Newsletter 4:44-47 U.S.A

Garg N, Manchanda G (2009) ROS generation in plants: boon or bane? Plant Biosys 143:8-96

Handel EV (1968) Direct microdeterminations of sucrose. Anal Biochem 22:280-283

Hasanuzzaman M, Nahar K, Gil SS, Fujita M (2014) Drought stress responses in plants, oxidative stress and antioxidant defense. In: Gill SS, Tuteja N (eds) Climate change and plant abiotic stress tolerance. Wiley, Weinheim, pp 209-249

Hodges DM, De Long JM, Forney C, Prange PK (1999) Improving the thiobarbaturic acid reactive substances assay for estimating lipid peroxidation in plant tissues containing anthocyanin and other interfering compounds. Planta 207:604-611

Homme PM, Gonzalez B, Billard J (1992) Carbohydrate content, frutane and sucrose enzyme activities in roots, stubble and leaves of rye grass (Lolium perenne L.) as affected by sources / link modification after cutting. J Plant Physiol 140:282-291

Hossain MA, Mostofa MG, Fujita M (2013) Cross protection by cold-shock to salinity and drought stress-induced oxidative stress in mustard (Brassica campestris L.) seedlings. Molecular Plant Breeding 4:50-70

Hosseini SM, Hasanloo T, Mohammadi S (2014) Physiological characteristics, antioxidant enzyme activities, and gene expression in 2 spring canola (Brassica napus L.) cultivars under drought stress conditions. Turkish journal agricultural. Forestry 38:1-8

Huang C, He W, Guo J, Chang X, Su P, Zhang L (2005) Increased sensitivity to salt stress in ascorbate-deficient Arabidopsis mutant. J Exp Bot 56:3041-49.

Jin J, Shan N, Ma N, Bai J, Gao J (2006) Regulation of ascorbate peroxidase at the transcript level is involved in tolerance to postharvest drought stress in the cut rose (Rosa hybrida L.) cv. Samantha. Postharvest Biol Tec 40:236-243

Kong FX, Hu W, Chao WL, Sang WL, Wang LS (1999) Physiological responses of Mexicana to oxidative stress of $\mathrm{SO}_{2}$. Environ Exp Bot 42:201-209

Kumar KB, Khan PA (1982) Peroxidase and polyphenol oxidase in excised ragi (Eleusine coracana cv. PR 202) leaves during senescence. Indian J Exp Bot 20:412-416

Li ZG, Luo L, Zhu LP (2014) Involvement of trehalose in hydrogen sulfide donor sodium hydrosulfide-induced the acquisition of heat tolerance in maize (Zea mays $L$.) seedlings. Bot Stud 55:20

Liu X, Hung C, Chen Q, Wu X, Zhang J (2013) Alleviates effects of exogenous trehalose on oxidative damage metabolism in Pleurotus pulmonaris under heat stress. Acta Hort Sin 40:1501-1150

Luo Y, Li F, Wang GP, Yang XH, Wang W (2010) Exogenously-supplied trehalose protects thylakoid mem- branes of winter wheat from heat-induced damage. Biol Plant 54:495-501

Ma C, Wang Z, Kong B, Lin T (2013) Exogenous trehalose differentially modulate antioxidant defense system in wheat callus during water deficit and subsequent recovery. Plant Growth Regul 70:275-285

Mahajan S, Tuteja N (2005) Cold, salinity and drought stresses: an overview. Arch Biochem Biophys 444:139-158

Mishra MK, Prakash V (2010) Response of non- enzymatic antioxidants to zinc induced stress at different pH in Glycine max L. cv. Merrill. Acad J Plant Sci 1:1-10 
Mostafa MG, Hossain MA, Fujita M (2015) Trehalose pretreatment induces salt tolerance in rice (Oryza sativa L.) seedlings: oxidative damage and co-induction of antioxidant defense and glyoxalase systems. Protoplasma 252:461-475

Murakeozy EP, Nagy Z, Duhaze C, Bouchereau A, Tuba Z (2003) Seasonal changes in the levels of compatible osmolytes in three halophytic species of inland saline vegetation in Hungary. J Plant Physiol 160:395-401

Nakano Y, Asada K (1987) Purification of ascorbate peroxidase in spinach chloroplast; its inactivation in ascorbatedepleted medium and reactivation by monodehydroascorbate radical. Plant Cell Physiol 28:131-140

Nelson NA (1944) (1944) photometric adaptation of the Somogyi method for the determination of glucose. J Biol Chem 153:375-380

Nounjan N, Nghia PT, Theerakulpisut P (2012) Exogenous proline and trehalose promote recovery of rice seedlings from salt-stress and differentially modulate antioxidant enzymes and expression of related genes. J Plant Physiol 169:596-604

Nounjan N, Theerakulpisut P (2012) Effects of exogenous proline and trehalose on physiological responses in rice seedlings during salt-stress and after recovery. Plant Soil Environ 58:309-315

Orabi SA, Sadak MS (2015) Alleviation of adverse effects of salinity stress on wheat (Triticum aestivum L.) by exogenous application of hydrogen peroxide. J Basic Appl Res Inte 8(4):287-303

Petridis A, Therios I, Samouris G, Tananaki C (2012) Salinity induced changes in phenolic compounds in leaves and roots of four olive cultivars (Olea europaea L.) and their relationship to antioxidant activity. Environ Exp Bot 79:37-43

Rady MM, Sadak MS, El-Bassiouny HMS, Abd El-Monem AA (2011) Aleviation the adverse effects of salinity stress in sunflower cultivars using nicotinamide and a-tocopherol Aust. J Basic Appl Sci 5(10):342-355

Ranwala AP, Miller WB (2009) Comparison of the dynamics of non-structural carbohydrate pools in cut tulip stems supplied with sucrose or trehalose. Postharvest Biol Technol 52:91-96

Repo-Carrasco-Valencia RAM, Serna LA (2011) Quinoa (Chenopodium quinoa Willd.) as a source of dietary fiber and other functional components. Cienc Tecnol Aliment 31:225-230

Sadak MS (2016a) Mitigation of salinity adverse effects on wheat by grain priming with melatonin. Int J Chem Tech Res 9(2):85-97

Sadak MS (2016b) Mitigation of drought stress on fenugreek plant by foliar application of trehalose. Int J Chem. Tech. Res. 9(2):147-155

Sadak MS, Abdelhamid MT (2015) Influence of amino acids mixture application on some biochemical aspects, antioxidant enzymes and endogenous polyamines of Vicia faba plant grown under seawater salinity stress. Gesunde Pflanzen 67:119-129

Sadak MS, Orabi SA (2015) Improving thermo tolerance of wheat plant by foliar application of citric acid or oxalic acid. Int J Chem Tech Res 8(1):111-123

Sánchez-Rodríguez E, Rubio-Wilhelmi MDM, Blasco B, Leyva R, Romero L, Ruiz JM (2012) Antioxidant response resides in the shoot in reciprocal grafts of drought-tolerant and drought-sensitive cultivars in tomato under water stress. Plant Sci 188-189:89-96

Snedecor GW, Cochran WG (1990) Statistical methods, 8th edn. lowa State University Press, Ames

Theerakulpisut P, Gunnula W (2012) Alleviation of adverse effects of salt stress on rice seedlings by exogenous trehalose. Asian J Crop Sci 4(4):405-15.

Vartainan N, Hervochon P, Marcotte L, Larher F (1992) Proline accumulation during drought rhizogenesis in Brassica napus var. Oleifera. Plant Physiol 140:623-628

Yemm EW, Cocking EC (1955) The determination of amino acids with ninhydrin. Analyst 80:209-213

Yemm EW, Willis AJ (1954) The respiration of barley plants. IX The metabolism of roots during assimilation of nitrogen. New Phytotol 55:229-234

\section{Submit your manuscript to a SpringerOpen ${ }^{\circ}$ journal and benefit from:}

- Convenient online submission

- Rigorous peer review

- Open access: articles freely available online

High visibility within the field

- Retaining the copyright to your article

Submit your next manuscript at $\boldsymbol{\nabla}$ springeropen.com 